\title{
EFFECT OF CARBAMIDE PEROXIDE BLEACHING WITH AND WITHOUT TOPICAL DESENSITIZING GELS ON ENAMEL ROUGHNESS, MICROHARDNESS, AND BOND STRENGTH TO ORTHODONTIC BRACKETS
}

\author{
Abeer A.M.M Elhatery* and Mohammed M. Ellaithy**
}

\begin{abstract}
Objective: The objective of this study was to evaluate, in vitro, the influence of two concentrations of carbamide peroxide bleaching agents with and without topical desensitizing gels on enamel microhardness, roughness, and shear bond strength to orthodontic metal brackets.

Methods: One hundred and sixty-eight (168) human extracted premolars for orthodontic purpose were obtained and randomly divided into seven groups $(\mathrm{n}=24)$ : Group 1, control group (Neither bleaching nor desensitizing); Group 2, bleached with 22\% carbamide peroxide; Group 3, bleached with $22 \%$ carbamide peroxide followed by Minerals desensitizing gel; Group 4, bleached with $22 \%$ carbamide peroxide followed by "D.M. Sense" desensitizing gel; Group 5, bleached with $35 \%$ carbamide peroxide; Group 6, bleached with $35 \%$ carbamide peroxide followed by Minerals desensitizing gel; Group 7, bleached with 35\% carbamide peroxide followed by 'D.M. Sense" desensitizing gel. Microhardness test and roughness measurements were carried on specimens immediately after finishing of treatment, using Vickers Diamond Microhardness Tester and Roughness Analyzer respectively. Only specimens for brackets shear bond strength (SBS) were stored for 7 days in distilled water after treatments and before testing. Shear bond strength were tested using Instron Universal Testing Machine
\end{abstract}

Results: Statistical significant differences were found between groups. Groups that received bleaching treatments only, showed greater deterioration in all tested properties than, groups received desensitizing treatments after bleaching treatment.

Conclusion: Application of desensitizing agent after in-home bleaching is highly recommended to minimize deleterious effects of bleaching agents.

KEYWORDS: Bleaching, Carbamide Peroxides, Enamel Roughness, Microhardness, Brackets shear bond strength.

* Lecturer at Dental Biomaterial Department, Faculty of Dentistry, Kafer Elsheikh University, Kafer Elsheikh, Egypt.

** Associate Professor at Orthodontic Department, Faculty of Dentistry, Tanta University, Tanta, Egypt. 


\section{INTRODUCTION}

Tooth whitening is a highly desirable esthetic treatment, as tooth color is one of the most important factors related to the patients' satisfaction with their appearance. With increasing the demand for such treatments that enhance aesthetic appearance, tooth bleaching became a common procedure in dental clinics. ${ }^{1,2}$ Mainly there are two types of tooth discolorations, intrinsic discoloration which is caused by incorporation of chromogenic material into dentin and enamel during tooth development stages or after its eruption. The other type of discoloration is extrinsic, which comes on the outer enamel surface after tooth eruption, it is also called extrinsic stain. Current vital and non-vital bleaching techniques employ oxidizing agents such as hydrogen peroxide or other peroxide releasing agents to brighten the teeth. ${ }^{3}$

There are different compositions and concentrations of bleaching agents available for home and clinical use that give dentists various options when planning for tooth whitening. Although carbamide peroxide (CP) has been proven successful in providing a long-lasting tooth whitening effect and indicated in $10 \%$ concentration as a safe selfadministered bleaching agent. ${ }^{2,4}$ But, many studies have reported altered surface morphology, decreased in microhardness from baseline values, and loss of dental hard tissue associated with such bleaching treatments even concentrations as low as $10 \% \mathrm{CP}^{5-8}$

Dental bleaching treatments are mainly based on the action of hydrogen peroxide, which is able to penetrate the tooth structure and release free oxygen radicals. These free radicals can oxidize the chromophore molecules which are responsible for tooth discoloration. Such chromophore molecules are mainly organic, but inorganic molecules may also be affected by these reactions. As the organic contents of enamel contribute to its integrity, it may be affected during these reactions, and so different adverse effects have been observed on bleached enamel..$^{9-11}$ Decreasing in enamel surface microhardness and increasing in both permeability and surface roughness are the most common adverse effects of bleaching agents whether hydrogen or carbamide peroxide. ${ }^{12}$

It is well established that, superficial characteristics of the enamel such as roughness, porosity, and depression could contribute to pigment precipitation ${ }^{13}$. So, after bleaching, coloring pigments may adhere more rapidly to such rough enamel surface and cause discoloration more easily than the original tooth. For these reasons, it is essential that the damaged enamel surface should be recovered after bleaching for a lasting bleaching effect. ${ }^{14,15}$ Fluoride becomes widely accepted as an important contributing factor in repairing microstructural defects of enamel through the adsorption and precipitation of calcium and phosphate present in saliva. ${ }^{12,14}$

Patients who need orthodontic treatment and choose esthetic brackets give much importance to the smile. Some of them have stained teeth and request that bleaching treatment be performed prior to orthodontic treatment. This is because they do not want to remain with stained teeth throughout all orthodontic treatment, which can last more than three years. According to Britto et $\mathrm{al}^{\mathbf{1 6}}$ tooth bleaching is indicated to improve the esthetics of the smile, and must be performed before restorative and rehabilitative procedures. Therefore, it is important to assess the influence of bleaching agents on the bond strength of brackets to enamel.

So, in this study the effect of two different concentrations of carbamide peroxides bleaching agents with and without topical application of desensitizing gels, on some surface properties of enamel (microhardness \& roughness) and bond strength of orthodontic brackets was in vitro evaluated and compared. The null hypotheses were that neither the bleaching agents, nor the topical application of desensitizing gels would affect such properties. 


\section{MATERIALS AND METHODS}

\section{Specimen Preparation}

One hundred and sixty-eight (168) human extracted premolar teeth for orthodontic purpose were obtained and visually examined to follow the inclusion criteria: intact crowns, absence of white spot lesions, cracks and fractures, or any other defects. Immediately after extraction, the samples were completely cleaned of gross debris, and autoclaved (Autoclave MK3000 12L III, Odontobras, Ribeirao Preto, SP, Brazil; 55.16.2102.6700) in individual plastic vials with distilled water for 15 minutes at $121^{\circ} \mathrm{C}^{17}$. After careful cleaning, the specimens were stored at $37^{\circ} \mathrm{C}$ in distilled water until use to avoid dehydration of tooth structure. Water was changed every day, to avoid bacterial growth.

Firstly, roots were cut from the crowns about 2 $\mathrm{mm}$ apical to the cemento-enamel junction using a low-speed diamond saw under water cooling. ${ }^{\mathbf{1 6 , 1 8 , 1 9}}$ Then each tooth was individually embedded in self-cured acrylic resin (Acrostone, Cairo, Egypt) with the labial surface parallel to the (ground) horizontal plane. All labial surfaces were left the enamel exposed for any necessary flattening and/or smoothen on procedures. ${ }^{14,20}$

Teeth were randomly assigned into 7 groups of 24 teeth each (Table 1)

Group 1: (Control group): Neither bleaching agent nor desensitizing gel was applied.

Group 2: According to manufacture instructions, teeth were bleached with $22 \%$ carbamide peroxide (WHITEsmile GmbH Weinheimer Straße 6, 69488 Birkenau Germany). The bleaching gel was placed in direct contact with the enamel surfaces for $2 \mathrm{~h}$ daily for 8 consecutive days.

Group 3: Exactly like group 2, but desensitizing gel (Minerals 'Enamel Booster" Beaming White, LLC 1205 NE 95TH ST STE A Vancouver, WA
98665-8960 USA) was applied daily after each bleaching session. ${ }^{21}$ Minerals was applied in about $1.0 \mathrm{~mm}$ pellicle to the enamel surface for 10 minutes according to manufacturer's instructions.

Group 4: Bleaching and desensitization were done exactly as described for group 3, except that, desensitizing gel (D.M. Sense. D.M. Trust Co. Minia, 21st Mahkma st, Al Minia, Egypt) was applied instead of Minerals gel.

Group 5: According to manufacture instructions, teeth were bleached with $35 \%$ carbamide peroxide (WHITEsmile GmbH Weinheimer Straße 6, 69488 Birkenau Germany). The bleaching gel was placed in direct contact with enamel surfaces for $1 \mathrm{~h}$ daily for 6 consecutive days.

Group 6: Exactly like group 5, except that desensitizing gel (Minerals "Enamel Booster") was applied daily in about $1.0 \mathrm{~mm}$ pellicle for 10 minutes after each bleaching session.

Group 7: Bleaching was done exactly like group 6, but desensitizing gel (D.M. Sense) was applied daily after each bleaching session instead of Minerals gel.

In each bleaching session, bleaching agent was applied on tooth enamel surface and covered with an individual tray for a well-controlled time. After finishing of the session, the specimens were thoroughly rinsed with running water for $1 \mathrm{~min}$. Only in groups 3, 4, 6, and 7 the desensitizing agents, according to the group, were applied daily on the specimens for ten minutes after perfect application and rinsing of the bleaching agents (N.B bleaching concentrations and bleaching time varied according to groups). The specimens were stored in distilled water at $37^{\circ} \mathrm{C}$ all the time, except during the experimental procedures (bleaching, desensitizing, bonding, and/or testing procedures). While the control group did not receive any treatment, and was stored in distilled water at $37^{\circ} \mathrm{C}$ all the time. 
TABLE (1) Study groups divided according to the bleaching agent and desensitizing gel.

\begin{tabular}{|l|l|l|}
\hline Group & Bleaching agent & Desensitizing \\
\hline $\begin{array}{l}\text { Group 1 (control) } \\
24 \text { specimens }\end{array}$ & & \\
\hline $\begin{array}{l}\text { Group } 2 \\
24 \text { specimens }\end{array}$ & $22 \%$ carbamide peroxide WHITEsmile. Germany. & - \\
\hline $\begin{array}{l}\text { Group } 3 \\
24 \text { specimens }\end{array}$ & $22 \%$ carbamide peroxide. WHITEsmile. Germany. & $\begin{array}{l}\text { Minerals 'Enamel Booster” Beaming White. } \\
\text { USA. }\end{array}$ \\
\hline $\begin{array}{l}\text { Group } 4 \\
24 \text { specimens }\end{array}$ & $22 \%$ carbamide peroxide WHITEsmile. Germany. & $\begin{array}{l}\text { D.M. Sense. D.M. Trust Co. } \\
\text { Egypt. }\end{array}$ \\
\hline $\begin{array}{l}\text { Group } 5 \\
24 \text { specimens }\end{array}$ & $35 \%$ carbamide peroxide WHITEsmile. Germany. \\
\hline $\begin{array}{l}\text { Group } 6 \\
24 \text { specimens }\end{array}$ & $35 \%$ carbamide peroxide WHITEsmile. Germany. & $\begin{array}{l}\text { Minerals “'Enamel Booster” Beaming White. } \\
\text { USA. }\end{array}$ \\
\hline $\begin{array}{l}\text { Group } 7 \\
24 \text { specimens }\end{array}$ & $35 \%$ carbamide peroxide WHITEsmile. Germany. & $\begin{array}{l}\text { D.M. Sense. D.M. Trust Co. } \\
\text { Egypt. }\end{array}$ \\
\hline
\end{tabular}

\section{Testing procedures}

\section{Microhardness Testing:}

Microhardness tests are commonly used to study the properties of different materials, and they are widely used to measure the hardness of natural teeth. This method is easy, quick, and requires only a tiny area of specimen surface for testing. ${ }^{8}$

One third of specimens in all previously mentioned groups was subjected to microhardness testing. Meaning that, microhardness test was carried on the buccal surfaces of (fifty-six) specimens, in which, eight specimens were randomly selected from each studied group. Surface microhardness measured immediately after finishing of each group treatment.

Microhardness was determined using a Vickers diamond (Microhardness Tester ZWICK/ROELL 2125 Barrett Park Drive, Suite107 30144 Kennesaw, GA USA), at a load of $50 \mathrm{~g}$, applied for 10 seconds. ${ }^{17}$ Four repeated measurements were made on surface of each specimen with about $100 \mu \mathrm{m}$ distance from each other and mean values were analyzed by oneway ANOVA and Tukey test $(p<0.05)$

\section{Surface Roughness Testing: (SR testing):}

The other one third of specimens in the previously mentioned groups was subjected to surface roughness testing. As in microhardness testing, roughness test was measured immediately after finishing of different treatments and it was carried on the buccal surfaces of (fifty-six) specimens i.e. on eight specimens randomly selected from each group. Surface roughness was measured using a Surftest SJ 201 (Mitutoyo Sul Americana Ltda, São Paulo, Brazil) roughness analyzer. Wax was used to mount the specimen horizontally, and then the tip of the analyzer crossed the central portion of the specimen. The average roughness ( $\mathrm{Ra}$ ) was determined from three diametrically opposed measurements.

\section{Brackets Bonding:}

Finally, there were eight specimens remain in each group, they were used to measure brackets shear bond strength. As previously mentioned tests, brackets bonding test was carried on the buccal surfaces of fifty-six specimens. But specimens were stored in distilled water for seven days after finishing of different treatments and before the brackets were bonded. 
Before bonding, the facial surfaces of the teeth were cleaned with a mixture of water and pumice. The teeth were rinsed thoroughly with water and dried with oil and moisture-free compressed air. Each tooth was etched with $37 \%$ phosphoric acid gel for 15 seconds (3M Dental Products, St. Paul, Minnesota, USA). Then, all teeth were rinsed with a water/spray combination for 30 seconds and dried until a characteristic frosty white etched area was observed. Low profile mini bicuspid metal bracket with $14.3 \mathrm{~mm}^{2}$ surface area was used. (American Orthodontics, Washington Avenue, Sheboygan, Wisconsin. USA).

The liquid primer of Transbond XT (3M ESPE, St Paul, Minn, USA) was applied to the etched surfaces and the brackets were bonded to the teeth with Transbond XT (3M Unitek). Any excess resin was removed with an explorer before curing. Then, a quartz-tungsten-halogen (QTH) light curing unit was used to cure the adhesive resin (Optilux 501, Kerr, Dansbury, CT, USA) for 40 seconds (20 seconds on the mesial and 20 seconds on the distal surface of the brackets).

\section{Measurements of the shear bond strength}

Immediately after bracket bonding, the embedded samples were secured in a jig attached to the base plate of a universal testing machine (Instron 3365, USA). A chisel-edge plunger was mounted in the movable crosshead of the testing machine and positioned such that the leading edge was aimed at the enamel-adhesive interface. A crosshead speed of $0.5 \mathrm{~mm} / \mathrm{min}$ was used and the maximum load necessary to debond the bracket was recorded. The force required to remove the bracket was measured in Newtons $(\mathrm{N})$, and the corresponding (SBS) 1 megapascal $(\mathrm{MPa})=1 \mathrm{~N} / \mathrm{mm} 2$ was calculated by dividing the force value by the bracket base surface area.

The mean and standard deviation values were calculated for each group. Data were explored for normality using Kolmogorov-Smirnov and Shapiro-Wilk tests and showed parametric (normal) distribution. Independent sample-t test was used to compare between two groups in related samples One-way ANOVA was used to compare between more than two groups in non-related samples.

The significance level was set at $\mathrm{P} \leq 0.05$. Statistical analysis was performed with IBM ${ }^{\circledR}$ SPSS ${ }^{\circledR}$ Statistics Version 20 for Windows.

\section{RESULTS}

All experimental groups showed lower microhardness mean values in relation to the control one with statistically significant difference between them, where $(\mathrm{p}<0.001)$. The highest mean value was found in the Control group (396.13 VHN \pm 4.52$)$, while the least value was found in \{Bleach 35\% (297.50 VHN \pm 7.76). (Table 2). As regard to the concentration of bleaching agents, there was a significant difference between both tested bleaching concentrations where $(\mathrm{p}<0.001)$. On using Minerals gel after bleaching, there was a statistically significant difference between $\{22 \%$ conc $\}$ (360.00 $\mathrm{VHN} \pm 4.54)$ and $\{35 \%$ conc $\}$ (326.38 $\mathrm{VHN} \pm 3.96)$, where $(\mathrm{p}<0.001)$. Also, on using D.M Sens after bleaching instead of Minerals, there was a statistically significant difference between $\{22 \%$ conc $\}(368.63 \mathrm{VHN} \pm 6.12)$ and $\{35 \%$ conc $\}$ (343.50 VHN \pm 3.16$)$ where $(\mathrm{p}<0.001)$. (Table 3).

All tested groups showed higher roughness mean values in relation to control one with significant difference between them, where $(p<0.001)$. The highest roughness value was found in Bleach $35 \%\}(0.42 \mu \mathrm{m} \pm 0.012)$, while the least value was in $\{$ Control $\}(0.29 \mu \mathrm{m} \pm 0.012)$. (Table 2). As regard to the concentration of bleaching agents, there was a significant difference between both bleaching concentrations. where $(p<0.001)$. Increasing the concentrations of bleaching agents resulted in increasing of the surface roughness. On using Minerals gel after bleaching, also there was an 
increasing in roughness, but to lesser extent, with a significant difference between $\{22 \%$ conc $\}$ and $\{35 \%$ conc $\}$ where $(\mathrm{p}=0.001)$. While, on using D.M Sens after bleaching, roughness increases but there was no significant difference between $22 \%$ and $35 \%$ concentrations where $(p=0.285)$. (Table 4).

Unfortunately, shear bond strength in all experimental groups showed lower mean values in relation to control one, with statistically significant difference between them, where $(p<0.001)$. The highest shear bond strength mean value was found in $\{$ Control\} (21.58 MPa \pm 1.97), while the least shear bond strength was found in \{Bleach $35 \%$ \}
(10.61 MPa 0.74). (Table 2). Both evaluated bleaching agents decrease the shear bond strength of orthodontic brackets. But the reduction in $\{35 \%$ conc $\}$ was greater than in $\{22 \%$ conc $\}$, as the shear bond strength were (10.61 MPa \pm 0.74$)$ and (12.50 MPa \pm 1.09$)$ respectively, with significant difference between them, where $(p=0.001)$. On using Minerals gel after bleaching, the shear bond strength still lower than control, but to lesser extent with no statistically significant difference between both evaluated concentrations, where $(\mathrm{p}=0.507)$. The same was found on using D.M Sens instead of Minerals with no significant difference between $22 \%$ and $35 \%$, where $(\mathrm{p}=0.463)$. (Table.5)

TABLE (2): The mean, standard deviation (SD) values of microhardness in VHN, roughness in $\mu \mathrm{m}$ and shear bond strength in MPa of control and all experimental groups.

\begin{tabular}{|c|c|c|c|c|c|c|}
\hline \multirow[t]{2}{*}{ Variables } & \multicolumn{2}{|c|}{$\begin{array}{c}\text { Microhardness } \\
\text { VHN }\end{array}$} & \multicolumn{2}{|c|}{$\begin{array}{l}\text { Roughness } \\
\mu \mu \mathrm{m}\end{array}$} & \multicolumn{2}{|c|}{$\begin{array}{c}\text { Shear bond strength } \\
\mathrm{MPa}\end{array}$} \\
\hline & Mean & SD & Mean & SD & Mean & SD \\
\hline Group 1 (Control) & $396.13^{\mathrm{a}}$ & 4.52 & $0.29^{\mathrm{d}}$ & 0.01 & $21.58^{\mathrm{a}}$ & 1.97 \\
\hline Group 2 (Bleaching 22\%) & $337.13^{\mathrm{d}}$ & 3.56 & $0.37^{\mathrm{b}}$ & 0.02 & $12.50^{\mathrm{c}}$ & 1.09 \\
\hline Group 3 (Bleaching 22\% + Miner) & $360.00^{c}$ & 4.54 & $0.34^{\mathrm{b}}$ & 0.01 & $16.96^{\mathrm{b}}$ & 1.34 \\
\hline Group 4 (Bleaching 22\% + D.M sens) & $368.63^{b}$ & 6.12 & $0.32^{\mathrm{c}}$ & 0.01 & $17.29^{b}$ & 1.40 \\
\hline Group 5 (Bleaching 35\%) & $297.50^{f}$ & 7.76 & $0.42^{\mathrm{a}}$ & 0.01 & $10.61^{\mathrm{c}}$ & 0.74 \\
\hline Group 6 (Bleaching 35\% + Miner) & $326.38^{\mathrm{e}}$ & 3.96 & $0.37^{\mathrm{b}}$ & 0.01 & $16.49^{\mathrm{b}}$ & 1.45 \\
\hline Group 7 (Bleaching 35\% + D.M sens) & $343.50^{\mathrm{d}}$ & 3.16 & $0.33^{\mathrm{c}}$ & 0.02 & $16.73^{b}$ & 1.57 \\
\hline P-value & \multicolumn{2}{|c|}{$<0.001 *$} & \multicolumn{2}{|c|}{$<0.001 *$} & \multicolumn{2}{|c|}{$<0.001 *$} \\
\hline
\end{tabular}

Means with different small letters in the same column indicate statistically significance difference, *; significant (p<0.05) ns; non-significant ( $p>0.05)$

TABLE (3): The mean, standard deviation (SD) values of microhardness in VHN of all groups.

\begin{tabular}{|c|c|c|c|c|c|c|c|}
\hline \multirow{3}{*}{ Variables } & \multicolumn{6}{|c|}{ Microhardness VHN } & \multirow{3}{*}{ P-value } \\
\hline & \multicolumn{2}{|c|}{ Bleaching } & \multicolumn{2}{|c|}{ Bleaching + Miner } & \multicolumn{2}{|c|}{ Bleaching + D.M sens } & \\
\hline & Mean & SD & Mean & $\mathrm{SD}$ & Mean & $\mathrm{SD}$ & \\
\hline $22 \%$ concentration & $337.13^{\mathrm{aC}}$ & 3.56 & $360.00^{\mathrm{aB}}$ & 4.54 & $368.63^{\mathrm{aA}}$ & 6.12 & $<0.001^{*}$ \\
\hline $35 \%$ concentration & $297.50^{\mathrm{bC}}$ & 7.76 & $326.38^{\text {ьв }}$ & 3.96 & $343.50^{\mathrm{bA}}$ & 3.16 & $<0.001 *$ \\
\hline P-value & \multicolumn{2}{|c|}{$<0.001 *$} & \multicolumn{2}{|c|}{$<0.001 *$} & \multicolumn{2}{|c|}{$<0.001 *$} & \\
\hline
\end{tabular}

Means with different small letters in the same column indicate statistically significance difference, means with different capital letters in the same row indicate statistically significance difference. *; significant $(p<0.05) \quad n s$; non-significant $(p>0.05)$ 
TABLE (4) The mean, standard deviation (SD) values of roughness in $\mu \mathrm{m}$ of experimental groups.

\begin{tabular}{|c|c|c|c|c|c|c|c|}
\hline \multirow{3}{*}{ Variables } & \multicolumn{6}{|c|}{$\begin{array}{l}\text { Roughness } \\
\qquad \mu \mathrm{m}\end{array}$} & \multirow{3}{*}{ P-value } \\
\hline & \multicolumn{2}{|c|}{ Bleaching } & \multicolumn{2}{|c|}{ Bleaching + Miner } & \multicolumn{2}{|c|}{ Bleaching + D.M sens } & \\
\hline & Mean & SD & Mean & SD & Mean & SD & \\
\hline $22 \%$ concentration & $0.370^{\mathrm{bA}}$ & 0.019 & $0.341^{\mathrm{bB}}$ & 0.011 & $0.318^{\mathrm{aC}}$ & 0.010 & $<0.001^{*}$ \\
\hline $35 \%$ concentration & $0.421^{\mathrm{aA}}$ & 0.012 & $0.368^{\mathrm{aB}}$ & 0.015 & $0.325^{\mathrm{aC}}$ & 0.016 & $<0.001^{*}$ \\
\hline P-value & \multicolumn{2}{|c|}{$<0.001 *$} & \multicolumn{2}{|c|}{$0.001 *$} & \multicolumn{2}{|c|}{$0.285 \mathrm{~ns}$} & \\
\hline
\end{tabular}

Means with different small letters in the same column indicate statistically significance difference, means with different capital letters in the same row indicate statistically significance difference. *; significant $(p<0.05) \quad$ ns; non-significant $(p>0.05)$.

TABLE (5): The mean, standard deviation (SD) values of shear bond strength in MPa of all groups.

\begin{tabular}{|c|c|c|c|c|c|c|c|}
\hline \multirow{3}{*}{ Variables } & \multicolumn{6}{|c|}{$\begin{array}{c}\text { Shear bond strength } \\
\text { MPa }\end{array}$} & \multirow[t]{3}{*}{ P-value } \\
\hline & \multicolumn{2}{|c|}{ Bleaching } & \multicolumn{2}{|c|}{ Bleaching + Miner } & \multicolumn{2}{|c|}{ Bleaching + D.M sens } & \\
\hline & Mean & SD & Mean & SD & Mean & SD & \\
\hline $22 \%$ concentration & $12.50^{\mathrm{aB}}$ & 1.09 & $16.96^{\mathrm{aA}}$ & 1.34 & $17.29^{\mathrm{aA}}$ & 1.40 & $<0.001 *$ \\
\hline $35 \%$ concentration & $10.61^{\mathrm{bB}}$ & 0.74 & $16.49^{\mathrm{aA}}$ & 1.45 & $16.73^{\mathrm{aA}}$ & 1.57 & $<0.001 *$ \\
\hline$P$-value & \multicolumn{2}{|c|}{$0.001 *$} & \multicolumn{2}{|c|}{$0.507 n s$} & \multicolumn{2}{|c|}{$0.463 \mathrm{~ns}$} & \\
\hline
\end{tabular}

Means with different small letters in the same column indicate statistically significance difference, means with different capital letters in the same row indicate statistically significance difference. ${ }^{*}$; significant $(p<0.05)$ ns; non-significant $(p>0.05)$

\section{DISCUSSION}

Tooth color is a very important issue in esthetic dentistry especially for patients that wish to enhance the appearance of their smiles. Although bleaching agents have been used for more than a century but, they have been increased in their popularity with the advent of home whitening techniques, which provide convenience and lower costs..$^{14,15}$ Nowadays, discolored teeth can be treated easily and successfully through noninvasive at-home vital tooth bleaching technique with custom trays. This technique is well accepted as a safe, conservative, low cost and effective esthetic procedure for treatment of discolored teeth ${ }^{19,20,22,23}$ The use of such at home self-administered carbamide peroxide bleaching gels, has become increasingly popular for whitening stained and discolored teeth, since their introduction by Haywood and Heymann 1989. ${ }^{20,24-26}$

Wide spreading of topical fluoridation especially after bleaching procedures is related to its ability to reverse the adverse effects of bleaching agents on enamel, besides its convenience, great acceptance by the patients, short time of application and highly satisfactory results. Moreover, there are different forms and shapes of topical fluoridation that could be applied by patients and/or dentists. ${ }^{27,28}$ 
There was a great controversial around the effect of bleaching agents on surface hardness, some studies have reported reduction in enamel microhardness following bleaching with peroxide, ${ }^{17,29-34}$ while others have reported no change in surface microhardness. ${ }^{35-38}$

The results of the present study agree with studies that reported a reduction in enamel microhardness after application of bleaching agents. ${ }^{17}$, 29-34 Because, in this study both evaluated carbamide peroxide concentrations when used alone were able to reduce enamel microhardness in a significant manner. This reduction in enamel microhardness may be explained by mineral loss from enamel after bleaching procedures, Preliminary studies reported that the application of peroxides could reduce the calcium and phosphate enamel content, as well as its fluoride concentration..$^{12,14,16,20}$ It is widely accepted that, surface hardness is used as a characteristic property to determine mineral loss, because it is an established technique for evaluating the mineralization rate of enamel. ${ }^{17}$ Beside this, carbopol, which is the thickening agent in most bleaching agents, can decrease the enamel microhardness during bleaching, as carbopol's high calcium-binding capacity and inhibits hydroxyapatite crystal growth..$^{17,39}$

Some qualitative study using SEM revealed that, some bleaching agents affect the human enamel morphology, resulting in porosity, surface depressions and produce some irregularities. Such morphological changes may also lead to a decrease in microhardness. ${ }^{14}$

As regard to surface roughness, the application of carbamide peroxide bleaching agents weather in (22\% or $35 \%$ concentration) without desensitizing gels application, resulted in significant increasing in enamel surface roughness in comparison to control group. This agree with authors who found that bleaching agents, hydrogen peroxide and carbamide peroxide, could bring many damage effects on enamel surface. Increasing in surface roughness is one of these common deleterious effects. ${ }^{40,41}$

Bleaching agents' breakdown into free radicals which are unspecific and characterized by instability, and high reactivity. These free radicals could decompose both organic and inorganic matrix of enamel to achieve their stability, yielding an alternation in the chemical composition and morphological structure of enamel..$^{39,42,43}$ These alternations in enamel structure, may explain the undesirable increasing in enamel roughness and decreasing in its microhardness. Moreover, free oxygen radicals that released during bleaching reaction, is likely to be one of the causes of the adverse effects of bleaching agents on enamel surface. As these free oxygens do not act in specific way and may act on the organic matrix of dental structures and break up the lipids and proteins of dental tissues. ${ }^{44,45}$ Besides, urea that present in bleaching agents and having a neutral $\mathrm{Ph}$, can also denature the proteins in enamel thus affecting its structural integrity and facilitate the process of demineralization, this also can explain the reduction in enamel surface microhardness and increasing in its roughness.$^{17}$

Shear bond strength (SBS) in the present study decreased in all tested groups in relation to control one. The greatest reduction was in the (group 5), followed by (group 2) which were bleached with carbamide peroxide in $35 \%$ and $22 \%$ concentrations respectively. These groups do not receive any desensitizing gel application after bleaching treatment. Some authors explained these changes in enamel bond strength subsequent to bleaching procedures by the presence of some residual bleaching agent that, may influence the bonding process and decrease bond strength. ${ }^{46}$ The reduction in bond strength of resin to enamel may also be related to the presence of free radicals of oxygen that interfere with the polymerization of resin material. So, it is advised to delay bonding to bleached enamel for at least one week after completion of bleaching process to eliminate or reduce the effects of residual oxygen. Within this period, residual oxygen must 
have been neutralized, thus not interfering with polymerization of resin composite for bonding ${ }^{16,47}$

According to Al-Salehi et $\mathrm{al}^{\mathbf{4 8}}$ there is direct proportional relationship between mineral loss and bleaching agent concentration. As they pointed out that bleaching agents based on $35-38 \%$ hydrogen peroxide showed significantly higher values of calcium loss compared to at-home gels (10\% carbamide peroxide). This could explain the more detrimental effect of higher concentration of carbamide peroxide (35\%) than lower concentration $(22 \%)$ on all tested properties (Microhardness, surface roughness and brackets shear bond strength).

Moreover, the present study verified the ability of two different desensitizing fluoride gel to reverse the possible adverse effects of carbamide peroxide bleaching agents. We omitted the storage of the specimens in artificial saliva during the entire experimental procedures to make sure that, the only source for remineralization process was through the applied desensitizing gels. On using both types of desensitizing fluoride gels after bleaching (22\% or 35\%), enamel microhardness showed lesser reduction than on using these bleaching agents alone. Meaning that, both evaluated gels had great ability to partly neutralize the deleterious effect of bleaching agents on enamel structure. D.M sens gel, had better effect on using after bleaching (22\% or $35 \%$ ) than Minerals gel, this could be explained by higher fluoride concentration in D.M sens gel.

The enamel surface roughness as well as enamel microhardness, had been improved on using both desensitizing fluoride gels after bleaching process. This agree with Cadenaro et al ${ }^{49}$ who reported that, topical application of fluoride is highly effective in reducing surface roughness after bleaching, and in contrary to the results obtained in China et al ${ }^{14}$

Improvement in brackets shear bond strength to bleached enamel surface after application of such desensitizing agents agree with Britto et al ${ }^{16}$ who explained this by ability of fluoride desensitizing gels in remineralizing enamel substrate and increasing its resistance to demineralization. More over fluoride ions released from desensitizing agent could promote ions change with enamel and form fluoridated apatite on tooth surface that could be related to the higher shear bond strength.

Nowadays, fluoride as an ion or combined with other elements, such as sodium fluoride, potassium nitrate, and more recently with ACP (Amorphous Calcium Phosphate), are being widely used in many desensitizing products. Such products are used during or after bleaching to overcome tooth sensitivity that commonly appear after bleaching process. ${ }^{49}$

There are great controversial around different fluoride therapies that applied on tooth structure to minimize enamel demineralization \& softening and increase its resistance to acids. This study proven the high ability of fluoride gels (topical NaF's gels) in high-frequency even in low concentrations in remineralizing the bleached enamel surface and offset the deleterious effect of bleaching agents. ${ }^{12,50,51}$ So, we can consider that, the major importance of fluoride is to be present at low but in constant concentrations to inhibit mineral loss and activate remineralization. ${ }^{20}$ This in agreement with Featherstone ${ }^{50}$ who established the optimal ability of fluoride application in preventing enamel softening, caries and increasing enamel resistance to acid and erosive by precipitation of strong calcium fluorapatite layer.

\section{CONCLUSION}

\section{Within the limitation of this study,}

Tooth whitening using carbamide peroxide bleaching agents is harmful to enamel structure, and deteriorate its properties.

Increasing the bleaching agent concentrations, increases their deleterious effects on enamel tooth structure. 
Application of desensitizing agent after in-home bleaching is highly recommended to minimize bad effects of bleaching agents.

High frequency of fluoride application is more effective even in low concentrations.

\section{REFERENCES}

1. Samorodnitzky-Naveh G.R., Geiger S.B., and Levin L.“ Patients' satisfaction with dental esthetics". J Am Dent Assoc. 2007 ; 138 (6): 805-8.

2. Chen HP, Chang CH, Liu JK, Chuang SF, and Yang JY. Effect of fluoride containing bleaching agents on enamel surface properties. J Dent. 2008; 36 (9) 718-25.

3. Christensen GJ. Bleaching teeth: practitioner trends. J Am Dent Assoc. 1997; 128: 16S-18S

4. Haywood VB, Leonard RH, Nelson CF, Brunson WD. Effectiveness, side effects and long-term status of night guard vital bleaching. J Am Dent Assoc. 1994; 125:1219-26.

5. Shannon H, Spencer P, Gross K, Tira D. Characterization of enamel exposed to $10 \%$ carbamide peroxide bleaching agents. Quintessence Int. 1993;24(1):39-44.

6. Wandera A, Feigal RJ, Douglas WH, Pintado MR. Homeuse tooth bleaching agents: an in vitro study on quantitative effects on enamel, dentin, and cementum. Quintessence Int. 1994; 25:541-6.

7. Ben-Amar A, Liberman R, Gorfil C, Bernstein Y. Effect of mouth guard bleaching on enamel surface. Am J Dent.1995;8 (1):29-32.

8. Strnad G and Imola B. Microhardness of teeth enamel on whitening combined with remineralization treatment. The 5th Edition of the Interdisciplinary in Engineering International Conference, Romania, 2011.

9. Sulieman M. A.,"An overview of tooth-bleaching techniques: chemistry, safety and efficacy," Periodontology 2000. 2008; 48 (1): 148-169.

10. T. Jiang, X. Ma, Y. Wang et al., "Investigation of the effects of $30 \%$ hydrogen peroxide on human tooth enamel by Raman scattering and laser-induced fluorescence," J biomed opt.2008; 13 ( 1) p. 014019.

11. Borges A.B, Torres C.R.G, de Souza P.A.B, Caneppele T.M.F, Santos L.F. T.F, and Magalhaes A.C. Bleaching Gels Containing Calcium and Fluoride: Effect on Enam- el Erosion Susceptibility. Inter J Dent. 2012, Article ID $347848: 6$ pages.

12. Rauen C.A, Filho J.C.C, Bittencourt B.F, Gomes G.M, Gomes J.C, and Gomes O.M.M. Effect of bleaching agents containing fluoride or calcium on enamel microhardness, roughness and permeability. Braz J Oral Sci. 2015; 14 (4):262-266.

13. Hattab FN, Qudeimat MA, Al-Rimawi HS. Dental discoloration: an overview. J Esthet Dent 1999; 11(6): 291-310.

14. China A.L.P, Souza N.M, Gomes Y. S. B, Alexandrino L.D and Silva C.M. Effect of Fluoride Gels on Microhardness and Surface Roughness of Bleached Enamel. The Open Dent J. 2014; 8: 188-193.

15. Kim YS, Kwon HK, Kim BI. Effect of nano-carbonate apatite to prevent re-stain after dental bleaching in vitro. $\mathrm{J}$ Dent 2011; 39 (9): 636-42.

16. Britto FAR, Lucato AS, Valdrighi HC, Vedovello SAS. Influence of bleaching and desensitizing gel on bond strength of orthodontic brackets. Dental Press J Orthod. 2015 MarApr;20(2):49-54.

17. Leandro G.A.L, Attia M.L, Cavalli V, do Rego M.A, and Liporoni, P.C.S. Effects of $10 \%$ carbamide peroxide treatment and sodium fluoride therapies on human enamel surface microhardness. General Dent. May 2008; Special Issu 274-77.

18. Khoroushi $M$ and Ghazalgoo A. Effect of desensitizer application on shear bond strength of composite resin to bleached enamel. Indian J Dent Res. 2013 JanFeb;24(1):87-92.

19. Meireles S.S, Fontes S.T, Coimbra L.A.A, Della Bona A, and Demarco F.F. Effectiveness of different carbamide peroxide concentrations used for tooth bleaching: an in vitro study. J Appl Oral Sci. 2012; 20 (2):186-91.

20. De Oliveira R, Paes Leme A.F, and Giannin M. Effect of a Carbamide Peroxide Bleaching Gel Containing Calcium or Fluoride on Human Enamel Surface Microhardness. Braz Dent J. 2005;16 (2): 103-106.

21. Britto FAR, Lucato AS, Valdrighi H, and Vedovello SAS. Influence of bleaching and desensitizing gel on bond strength of orthodontic brackets. Dental Press J Orthod. 2015 Mar-Apr; 20 (2) :49-54.

22. Auschill TM, Hellwig E, Schmidale S, Sculean A, Arweiler NB. Efficacy, side-effects and patients' acceptance of different bleaching techniques (OTC, in-office, at-home). 
Oper Dent. 2005; 30 (2): 156-163.

23. Boksman L. Current status of tooth whitening: Literature review. Dent Today 2006; 25:76-79.

24. Haywood VB, Heymann HO. Nightguard vital bleaching. Quintessence Int 1989;20:173-176.

25. Braun A, Jepsen S, Krause F. Spectrophotometric and visual evaluation of vital tooth bleaching employing different carbamide peroxide concentrations. Dent Mater 2007; 23: 165-169.

26. Matis BA, Cochran MA, Eckert G. Review of the effectiveness of various tooth whitening systems. Oper Dent. 2009; 34: 230-5.

27. Delpem A.C.B, Brighenti a.L, Vieira A.E.M, and Cury J.A. In vitro comparison of the cariostatic effect between topical application of fluoride gels and fluoride toothpaste. J Appl Oral Sci 2004; 12(2):121-6.

28. Burgmaier GM, Schulze IM, Attin T. Fluoride uptake and development of artificial erosions in bleached and fluoridated enamel in vitro. J Oral Rehabil 2002;29:799-804.

29. Justino LM, Tames DR, Demarco FF. In situ and in vitro effects of bleaching with carbamide peroxide on human enamel. Oper Dent 2004; 29(2): 219-25.

30. Basting RT, Rodrigues AL Jr, Serra MC. The effects of seven carbamide peroxide bleaching agents on enamel microhardness over time. J Am Dent Assoc 2003; 134(10): 1335-42.

31. Attin T, Betke H, Schippan F, Wiegand A. Potential of fluoridated carbamide peroxide gels to support post-bleaching enamel rehardening. J Dent 2007; 35(9): 755-9.

32. Maia E, Baratieri LN, Caldeira de Andrada MA, Monteiro $\mathrm{S}$ Jr, Vieira LC. The influence of two home-applied bleaching agents on enamel microhardness: an in situ study. J Dent 2008; 36(1): 2-7.

33. Rodrigues JA, Marchi GM, Ambrosano GM, Heymann HO, Pimenta LA. Microhardness evaluation of in situ vital bleaching on human dental enamel using a novel study design. Dent Mater 2005; 21(11): 1059-67.

34. Al-Salehi SK, Wood DJ, Hatton PV. The effect of $24 \mathrm{~h}$ nonstop hydrogen peroxide concentration on bovine enamel and dentine mineral content and microhardness. J Dent 2007; 35(11): 845-50.

35. Sulieman M, Addy M, Macdonald E, Rees JS. A safety study in vitro for the effects of an in-office bleaching sys- tem on the integrity of enamel and dentine. J Dent 2004; 32(7): 581-90.

36. Joiner A. Review of the effects of peroxide on enamel and dentin properties. J Dent 2007; 35(12): 889-96.

37. Joiner A, Thakker G, Cooper Y. Evaluation of a $6 \%$ hydrogen peroxide tooth whitening gel on enamel and dentine microhardness in vitro. J Dent 2004; 32 (1): 27-34.

38. Zantner C, Beheim-Schwarzbach N, Neumann K, Kielbassa AM. Surface microhardness of enamel after different home bleaching procedures. Dent Mater. 2007; 23(2): 243-50.

39. Basting RT, Rodrigues AL Jr, Serra MC. The effect of $10 \%$ carbamide peroxide, carbopol and/or glycerin on enamel and dentin microhardness. Oper Dent 2005; 30:608-616.

40. Dominguez JA, Bittencourt B, Michel M, Sabino N, Gomes JC, Gomes OM. Ultrastructural evaluation of enamel after dental bleaching associated with fluoride. Microsc Res Tech. 2012; 75: 1093-8.

41. Markovic L, Jordan RA, Lakota N, Gaengler P. Micromorphology of enamel surface after vital tooth bleaching. J Endod. 2007; 33: 607-10.

42. Basting RT, Rodrigues AL Jr, Serra MC. The effects of seven carbamide peroxide bleaching agents on enamel microhardness over time. J Am Dent Assoc 2003;134:13351342 .

43. de Oliveira R, Basting RT,Rodrigues JA, Rodrigues AL Jr, Serra MC. Effects of a carbamide peroxide agent and desensitizing dentifrices on enamel microhardness. Am J Dent 2003;16:42-46.

44. Hegedüs C, Bistey T, Flora-Nagy E, Keszthelyi G, Jenei A. An atomic force microscopy study on the effect of bleaching agents on enamel surface. J Dent. 1999; 27: 509-15.

45. Minoux M, Serfaty R. Vital tooth bleaching: biologic adverse effects - a review. Quintessence Int. 2008; 39: 645-59.

46. Maryam Khoroushi, and Ali Ghazalgoo. Dental Materials research Center and Department of Operative Dentistry. Isfahan University of medical science, Isfahan, Iran. Effect of desensitizer application on shear bond strength of composite resin to bleached enamel. Indian J Dent Res. 2013;24(1):87-92.

47. Martin JM, Almeida JB, Rosa EA, Soares P, Torno V. Rached RN, Mazur RF. Effect of fluoride therapies on the 
surface roughness of human enamel exposed to bleaching agents. Quintessence Int. 2010;41(1):71-8.

48. Al-Salehi SK, Wood DJ, Hatton PV. The effect of $24 \mathrm{~h}$ non-stop hydrogen peroxide concentration on bovine enamel and dentine mineral content and microhardness. J Dent. 2007; 358:45-50

49. Cadenaro M, Breschi L, Nucci C, et al. Effect of two inoffice whitening agents on the enamel surface in vivo: a morphological and non-contact profilometric study. Oper Dent 2008; 33(2): 127-34.

50. Featherstone JD. The science and practice of caries prevention. J Am Dent Assoc 2000;131 (7): 887-899.

51. Paes Leme AF, Tabchoury CP, Zero DT, Cury JA. Effect of fluoridated dentifrice and acidulated phosphate fluoride application on early artificial carious lesions. Am J Dent 2003; 16: 91-95. 